\title{
STRATEGIES CONSTRAINS IN RENDERING ISLAMIC RELIGIOUS COLLOCATIONS FROM ARABIC INTO ENGLISH
}

\author{
Amin Ali Al Mubarak \\ Department of English, Faculty of Language and Cultural, \\ University of AL Imam AL Mahdi, Sudan \\ E-mail: amino.last25@gmail.com
}

APA Citation: Mubarak, A. A. A. (2019). Strategies constrains in rendering Islamic religious collocations from Arabic into English. Indonesian Journal of Learning and Instruction, 2(1), 114. doi: 10.25134/ijli.v2i01.1679.

\begin{abstract}
This particular study investigates the problems found in the strategies adopted by students in translating certain lexical collocations of the Islamic religious texts. For that purpose, a purposive sample of 41 B.A, English students enrolled in the academic year of 2017-2018 at the Arts College had been selected as participants in this study. Thus, the primary objective of the study is to determine if these Sudanese students faced any problem when translating Islamic religious collocations from Arabic into English. Therefore, the researcher employed the descriptive approach to identify the problems faced by students in using several strategies for translation. As for data collection method, a test, which consisted of specific lexical collocations terms, had been carried out to analyse the obstacles that the students faced when translating Islamic religious collocations terms from Arabic into English. Hence, some main issues that were identified from the findings were reviewed in a wholesome manner and wherever possible, links were made to associate the themes to the literature examined, besides further extending the research scope via comparison with other literature in light of the finding. Finally, some recommendations are given at the end of the research mainly for students to improve their skills in translating Islamic lexical collocations from Arabic into English.

Keywords: Arabic; collocations; English; religious; translational.
\end{abstract}

\section{INTRODUCTION}

Translation has been the oldest form of communication devised by humans to convey ideas, thoughts, and culture especially to overcome the issue of understanding different languages. The needs for translation are expanding these days due to the rapid advancement of science, culture, and innovation. Nevertheless, the process of translation has raised a number of substantial linguistic problems, including those related to context, grammar, and culture.

Besides, applying distinctive translation strategies is one of the apparatuses translators use in order to overcome issues and difficulties related to translation. Saying that, religious collocations are among the prominent translation problems, especially where translation involves two differing languages like Arabic and English, which display great variances in cultural and linguistic aspects.
Hence, the enthusiasm for the translation of collocations originates from their extraordinary significance in language. Additionally, translation plays a fundamental role in the coherence aspect of the structure of a language. The translation of collocations, as one realizes, is an unending battle to match proper nouns with appropriate verbs, correct verbs with apt proper nouns, and suitable adjectives with proper nouns. Moreover, translating religious collocations has been considered as a high-level challenge, especially for translation from Arabic into English. This is because the translator's deadlock arises from the fact that only two possibilities are available when translating religious collocations: First, the translator should be familiar with the terms, comprehend the sense of the terms, and be well acquainted with the target language version of it. Second, the translator should be accustomed with the 
term manifestations in the source language or its rendered equivalents in the target language.

The present study investigates the issues that revolve around the problems faced by Sudanese students when translating Islamic Religious collocations from Arabic into English. The problem statement show that Translation of religious collocations differs greatly from any sort of translation. It is a standout amongst the hardest kind of translation, as it needs a great deal more exactness, deliberateness, and mindfulness.

However, the biggest problems lie in vanquishing ideational obstacles in translation, as well as in addressing the terms. Furthermore, the need of deciphering Islamic collocations from Arabic into English has been an absolute necessity, thus gives a challenge for Muslim translators in general. In addition, religious expressions are commonly utilized outside of the religious context through conversational, political, and various sorts of discourse to bolster non-religious causes.

Religious translation is the most dangerous type of translation because it manages unique and delicate writings - God's words. Hence, an enormous problem lies in making translation of them into a target language. Religious collocations posture difficulties to students because religion is an important institutional network that binds people to one another. Therefore, a translator ought to acknowledge the variances between Arabic ideas and convictions against Western ones. Indeed, Arabic and English have unique linguistic systems; each possesses exclusive religious terminology. Besides, the category of religious collocations in each language constitutes sovereign religious territory, in which a term in a religion in one language may vary from the meaning of the similar term in another language.

In addition, the absence of congruency between the two unique religious expressions adds to the issues faced by translators. Therefore, this study determines the strategies employed by B.A students at the Arts College University of AL Imam Amdahl Sudan when collocations in religious texts are translated from Arabic into English. While the objective is to explore the various strategies used by students due to the difficulties faced in translating collocations in religious texts from Arabic into English. Translating Islamic religious items is indeed challenging. Besides, it appears to be one of the most common difficulties and problems faced by translators.

Studies in the area of deciphering collocations from the source language to the target language have revealed that the correlation between strategies and errors is significant. Simply put, erroneous renditions of collocations ascribed, in addition to other things, to the strategies that translators tend to utilize to handle the issue of translating religious collocations. Dalby ( 1998 ) revealed that Arabic and English languages have various settings and derive from differing language families, whereby the Arabic is organized as an affiliate of the Semitic family of languages, while English is a branch of the Indo-European language family.

The Arabic in this research context, is defined as the representative language spoken in more than 15 countries in the Middle East, whereas the English is an Indo-European language and it is the representative language of England, the America, and a majority of the Commonwealth nations. As such, both Arabic and English syntactically display varied structures. For instance, Arabic is for the most component, an artificial language. For instance, the nouns change for case, while the verbs change for mood. Phonologically, Arabic and English differ in phonemic lists.

Moreover, if one needs to measure the real obstacles that revolve around translation, one cannot dismiss the environmental space within the Arabic and English settings, which presents as a gap between the Arab culture and the English culture. Jemiriye (2005) has pointed out that the correlations between religions, language, and culture are incredibly interconnected. Religion based on culture is also closely related to language. Besides, language relies on familiarity and one that is never knowledgeable can never be expressed in a language.

Every religious familiarity will consequently carry a religious language, thus a holy culture. The culture within which a religion is built paints the language and the 
very concept of the related religion, therefore, cannot be differentiated. Furthermore, in the relationship between language and culture, a question always pops up: 'which one contains the other?' Language expresses religion and culture, but at the same time, language is cultural. Interestingly, there is religious language, religious culture, language culture, and culture of language. All these perspectives cover the interrelatedness of religion, language, and culture. More importantly, religion is a way of belief and devotion to full rights. Besides, religion is the human seeking for God and His response to our plead.

Religion includes respect, faithfulness, personal commitment, and serving God with religious devotion. In fact, it resembles a system of belief and respect with multiple faces like spiritual and organizational. One can say that it is the professional perform or faith in the existence of supernatural powers or influences that control humanity, nature or destiny of a man. Therefore, the culture is such a common expression whose usage extends across many academic disciplines. It is, hence, worthwhile to show the broad scope of culture seriously, but in a brief manner.

The term 'collocation' is utilized broadly with various meanings by linguists. For instance, Moon (1998) alluded to syntagmatic and paradigmatic connections of words. In another isolated approach, Carter (2012) contended that collocation is the common cooccurrence of words within a particular span recognized to be four words to either side of the specified focal word or node. This stance is also known as the "Frequency-Based Method," which goes back to (Firth, 1957).

Nonetheless, it has been improved considerably by Halliday (1966) as collocation can be viewed as a sort of word-combination, most commonly as one that is static to some degree, but not in a wholesome manner. This outlook is also known as the "Phraseological Approach", which has been widely accepted by academics lengthily working in fields of pedagogy and lexicography, such as that of (Cowie, 1981). The Islamic religious item is linguistic-derived, a word or a string of words that is peculiar to a particular language and communicates it precisely (Esposito, 2004).

Abdelwali (2007) asserted that is an item or a group of specific sounds that allude to a particular significance or implication. If one considers the Islamic religious items as culture-specific concepts or culture-bound items, then these definitions need to be based on the viewpoints recommended by outstanding researchers in the field of translation, as well as linguistics.

In addition, Peter (1988) claimed that culture-bound words are uniquely "attached to the lifestyle and its appearances are peculiar to a group that uses a particular language as a tool of expression". On the other hand, Schwartz and Rubel (2005) defined culturebound as "thoughts in any language that are unique to that language or to the culture linked to that language, which leads to a social gap between speakers of various languages."

Meanwhile, in conjunction to religious lexical items, Elewa (2014) has categorized them into three groups within the Islamic setting: 1. Unfamiliar Islamic terms that are only utilized as part of Islamic settings, for instance, alkhul' (divorce for payment by the wife) and altaqiyyah (dissimulation). 2. Wellknown Islamic terms that are just utilized as part of non-Islamic setting, for instance, alfat-h (liberation) and alwala' (allegiance to Muslims). 3. Recognizable Islamic terms that are utilized as part of non-religious contexts, however, do not clearly look as though they are used as part of some particular Islamic route in the source text.

Ghazala (1995) categorized the Islamic religious items into three groups: 1 . New things that do not exist in the Arabic language before Islam, such as Qur'an and affliction2. Familiar Arabic items that Islam has given fresh ramifications, for example, Hajj and Salah 3. Things that are now known and utilized as part of the Arabic language, for instance, $\mathrm{K}^{\mathrm{ee}} \mathrm{aba}$ The primary issue in translating collocation heavily relies upon finding the privilege lexical, as well as cultural equivalent, for such items. Hence, one of the chief challenges faced by a translator of Islamic religious items is to settle on which 
cultural issues ought to take significance: the cultural aspects of the target language, the cultural dimensions of the source language, or perhaps, a combination of the two. For example, Nida (1964) gave significance to the cultural aspects of the target text when emphasis was projected upon the semantic and the pragmatic nature of the meaning. He also contended against static or unchanged meaning of words.

According to Nida (1964), the practical nature inferred in the meaning of words is more significant, thus, the meaning of words could be conveyed through unique circumstance, which could be altered by the culture one adopts. In addition, claimed that cultural translation refers to "the translation, in which the content of the message is modified to fit in with the receptor culture, besides determining the information that is presented, but not linguistically verifiable in the original (Nida, 1969)." Therefore, one's decision of a certain cultural strategy may result in sourceculture bound translation in the form of either foreignization or domestication.

Studies in the field of translating collocations from the source language to the target language have revealed that the relationship between strategies and mistakes is rather consistent. For example, scientists like Al-Khanji and Hussein (1999), Zughoul and Abdul-Fattah (2003), and Bahumaid (2006) have broadly explored the procedures adhered either by English Foreign language or by translators to overcome the difficulties encountered in translating collocations.

Al-Khanji and Hussein (1999) explored the nature of problems that students experienced in learning collocations, as well as the strategies utilized when the learners are incapable of translating lexical words accurately. In fact, the test comprised of 50 collocational terms that appeared as recurrence in textbooks and English courses. The outcomes demonstrated that the learners' inappropriate responses reflected three classes; one depended on their source language, such as literal transliteration, which is considered as a negative transfer. Meanwhile, the second depended on target language semantic continuity, whereby the learners substituted a lexical item by another one with mutual individual semantic elements with it, whereas the third classification refers to lexical diminishment strategy.

Other than that, Zughoul and AbdulFattah (2003) carried out a study among English Foreign language learners at the university level for both graduate and undergraduate levels. The researchers were determined to discover the capability of English Foreign language learners in translating collocations, as well as the strategies utilized in producing Arabic collocations. The results of the study revealed that the overall execution of the subjects in the target collocations had been unsatisfactory. Nevertheless, twelve appropriate strategies had been determined and listed in conjunction to the objective of the study, which are: literal translation, avoidance, graphic ambiguity, overgeneralization, quasi-metaphorical similarity, assumed synonymy, derivativeness, imitation of literary style, idiomaticness, paraphrase and circumlocution, substitution, and finally, false target language assumption.

Meanwhile, Bahumaid (2006) investigated the techniques that had been utilized by translators in rendering collocations, whose target language equivalents were obscure to them. The findings reflected that the translators did resort to many procedures. He carried out his study upon four Arab university teachers who taught translation. The two-section translation test was comprised of thirty sentences on contextualized collocations of various sorts. The collocations that were selected for the test had been of the general kind so as "to make noise", while the others were connected with a particular register. The findings demonstrated that culture-bound and in register-specific caused enormous difficulty in translation, whereas collocations with severe implications were relatively easier to translate. Moreover, the translators utilized certain strategies, for instance, using synonyms or near-synonyms, providing meaning of the collocations, attempting accurate renditions, and finally, avoiding translation all together.

On the other hand, Lörscher (1991) has alluded to translation issues experienced by 
translators, even by the expert, as "transfer problems. Such problems are ascribed to challenges in interpreting meaning carried by the mother tongue language text, and not by the lexical or semantic contrasts between languages. In addition, translation strategies are characterized as conscious procedures, which the subjects utilize to resolve translation issues and hurdles. Accordingly, translation strategies have their beginning point in acknowledging an issue by a subject, and their termination in a possibly preparatory solution to the problem or recognition of the insolubility of the subject at a given point in time."

Shunnaq (1993) analyzed the subject of emotive language in translation, which highlighted the diverse angles on lexical incongruence in Arabic-English translation due to the aspect of emotiveness in Arabic. On top of that, he sorted numerous types of emotive expressions into (neutral), (-emotive), and (+emotive). Next, he grouped the primary sources of emotive expressions into two: cultural expressions and figures of speech. In addition, he debated certain Arabic lexical items, which are emotive by their inclination, and contended how emotive implication could become a method of management in the field of translation.

Additionally, Shunnaq (1993) asserted that translating an Arabic emotive expression is definitely not a simple job because it involves the connotative meaning that is exceptionally a challenge to convey. Simply put, Shunnaq (1993) concluded that since total consistency in translating Arabic emotive expressions has always appeared as an impossible task; a translator has to resort to, footnote, paraphrase, exemplify, and gloss to preserve or retain the connotative meaning of the Arabic emotive expressions.

According to Dweik and Abu Shakra (2011), the troubles and issues that translators commonly experience while deciphering lexical and semantic contextualized collocations in three Arabic religious texts: the Holy Quran, the Hadith, and the Bible. They observed that the collocations displayed a noteworthy predicament among M.A. students pursuing translation program, especially when translating the collocations in religious texts. Their study further revealed that translators did confront the glitches that emerge in lexical and semantic collocations. Therefore, they suggested that translators of religious texts ought to be acutely aware of the nature of both lexical and figurative collocations. They highlighted that translators ought to understand the variances between Arabic ideas and convictions, in comparison to Western ones, besides evading literal translation by considering the context as a critical factor.

Other than that, Chebbo (2006) claimed that translators of religious texts from Arabic into English should consider several essential aspects while deciphering these 'sensitive' texts from Arabic into English. The translation of Arabic religious texts incorporates not just some issues at a linguistic level, with lexical and syntactic manipulation, as well as reformulation of concepts, but additionally, ideational obstacles that should intercede between the source text producer and reader.

Ivir (1987) proposed seven strategies: definition, translation, substitution, literal, addition, lexical creation, omission, borrowing, in conjunction to translation. Meanwhile, Hervey et al. (1992) suggested utilizing cultural borrowing, cultural transplantation, communicative translation, exoticism, and calque. Newmark (1988) highlighted employing naturalization, transference, shift, cultural equivalent, functional equivalent, descriptive equivalent, synonymy, and paraphrase through translation, or transposition, modulation, recognized translation, translation label, compensation, componential analysis, reduction, as well as expansion. The process of seeking for adequate collocations has to heavily consider exertion on the part of the translator, who ought to in any event attempt to give a target language translation, which is equivalent in both meanings and use of source language collocations.

Nevertheless, when translators fail in finding a corresponding target language equivalent to the lexical item in the source language, a few strategies are adopted as the 


\section{Amin Ali Al Mubarak}

Strategies constrains in rendering Islamic religious collocations from Arabic into English

solution to the problems experienced. For instance, Krings (1986) expressed their support towards translators who fall back on various strategies "if the idea of translation strategy is of an observational value, it should be connected to translation issues. This is because; strategies are developed when the translation cannot be carried out automatically." On the other hand, Garcia (1996) asserted diverse procedures for the translation are executed to accomplish a partially successful transfer when these problems in translation frequently get to be distinctly unavoidable.

Newmark (1989) acknowledged the issues that fellow translators have to face at various stages, and thus formulated certain strategies that could assist translators overcome these difficulties, whereby "the translator during the process of translation, is continually attempting to take care of a thousand little issues with regard to a vast one." Hence, seeking for suitable collocations in translation is indeed a consistent struggle. These situations, nevertheless, can be settled if "translators rely on upon specific strategies, which might be very powerful when dealing with linguistic resemblances, however prompt to significant issues in case of cultural disparity".

In addition, Peter (1988) has offered several techniques related to translation based on various understandings of strategies. These strategies are literal translation, word-for-word translation, faithful translation, semantic translation, free translation, adaptation translation, idiomatic translation, and communicative translation. Moreover, he stressed that communicative translation as a strategy where "a translator endeavors to render the exact contextual meaning of the source language in such a way that both content and language are promptly worthy and conceivable to the readership."

Naudé (2002) provides the following assumptions for the translation of religion terms: a) Translation of religion terms is a way of movement, which is similar to the translation of other terms, which belongs to a culture distant from the target readers in time and space. This means; the best translation approach available should be employed by the translators of religion terms. It also means the translators of religion texts should have sufficient translation capabilities; b) Two conditions can result in an extreme difference between cultures. First, the deficient cultural background information makes it achievable to set up consistency between what is said and what is known. Second, non-vocal and vocal behaviors do not suit because one that is nonvocal cannot be interpreted corrected; c) Sacred texts cannot be handled similar to that with communicative meaning in modern societies for they vary in their social and cultural settings. Therefore, the translation of theses text, by no means, can rely on equivalent standards; and d) Translation consists of a series of resolutions made by the translator, bearing in mind the contradictory requirements between the source text and the source culture on one hand, and those of the target language and the target culture on the other, in light of the purpose of the intercultural communication.

Similarly, Larson (1984) added that "terms that transact with the religious aspect of a culture are generally the most troublesome, both in the analysis of the source vocabulary, as well as in seeking for the best receptor language correspondence. The reason is that these words are impalpable and a large portion of the practices are so automatic to the point that the speakers of the language are not as aware of the various parts of meaning involved." On top of that, Ghazala (2002) recommended utilizing six sorts of equivalents to translate related Islamic terms and expressions: explanatory equivalent, referential equivalent, functional equivalent, cultural equivalent, religious equivalent, and connotative equivalent. For example, the words "halal" and "haraam" have literal equivalents in English as "Permissible" and "forbidden". Nonetheless, these equivalents do not convey the extra levels of social and religious meaning that Arabic terms denote. This is because; the terms "halal" and "haraam" in the Islamic culture refer to a wide number of practices and customs that are permitted (or not permitted) under the Islamic law. Furthermore, they refer to specific Islamic 
laws governing food and drinks. As such, translation of such terms just by providing their dictionary equivalents is yet again insufficient.

\section{METHOD}

Since this study had been carried out to determine the problems encountered when employing several strategies in translating Islamic Religious collocations from Arabic into English. A test was designed to include a reasonable number of questions (i.e., 12 items) with simple structures. In the study, a test was conducted to determine if the participants could translate religious terms from Arabic to English.

The sample is comprised of undergraduate students who were enrolled in English language program during the second semester of 2016/2017 at Arts College University of AL Imam Amdahl Sudan. Hence, a sample of 41 undergraduate students majoring in translation had been selected to participate in the study. Considering the intent of the survey was to determine the constraints in rendering Islamic Religious collocations from Arabic into English, recruiting a sample of undergraduate students majoring in translation would definitely fulfill this objective.

A test was carried out to determine if Islamic religion collocations had posed as a problem to students when translating from Arabic into English. In this study, the number of students involved was 35 . Hence, several aspects like right translation, wrong translation, transliteration, incomplete meaning, and no answer were obtained and indicated in percentage for each category.

\section{RESULTS AND DISCUSSION مُريدُ شَنْيًَانُ (Cursed devil)}

Figure 1 shows the frequency count of responses to the statement مُرِيد شَنْيَطَانُ (cursed devil). Of the 41 participants, forty-six percent gave the wrong translation to the collocation مُرِيدُ شَيَطَانُ , while only fourteen percent provide the correct translation. Meanwhile, thirty-four participants used transliteration to render the collocation شُرِيد شَيََْانُ However, twelve percent of the participants gave incomplete meaning, whereas four percent left blank answer. Figure 1 describes the results from the translation test carried out among the thirtyfive participants.

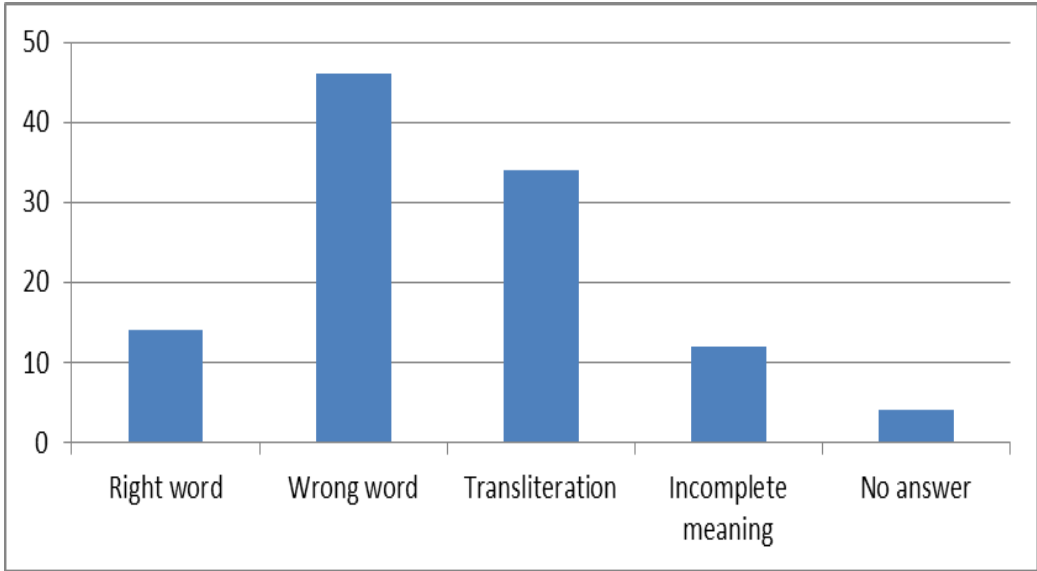

Figure 1. Frequency count of responses to the statement cursed devil

\section{وَالثََّّ الخير (Good and evil)}

Figure 2 shows the frequency count of responses to the statement وَالثثَّر الخير (good and evil). Out of the 41 participants, forty-three percent of the participants translated wrongly, while forty-eight percent translated accurately for the collocation وَالثُّر الخير. Other than that, seven participants used transliteration to render the collocation وَالثَّر الخير. However, one percent of the participants give incomplete meaning and blank answer each for the collocation وَالثَّر الخير. Figure 2 portrays the results from the translation test carried out upon the thirty-five participants. 
Amin Ali Al Mubarak

Strategies constrains in rendering Islamic religious collocations from Arabic into English

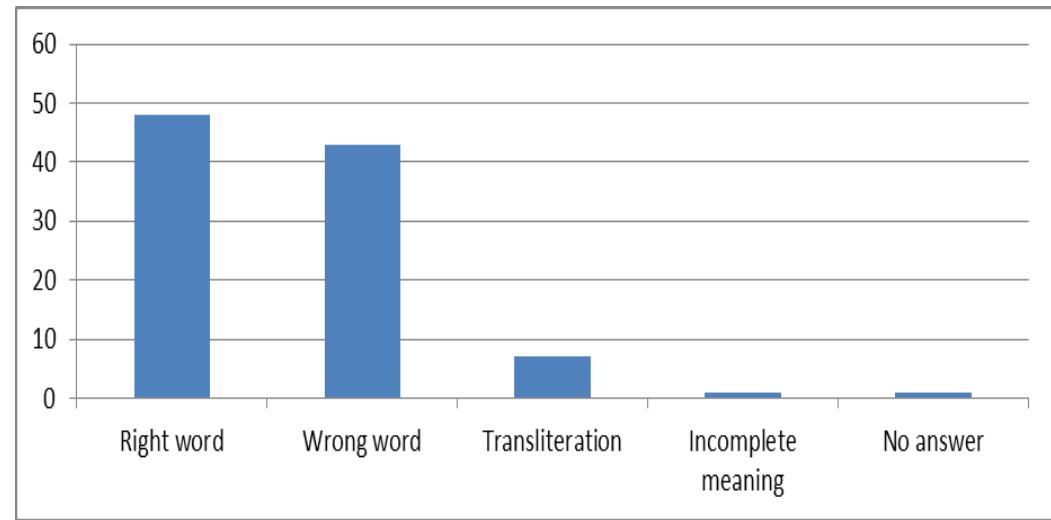

Figure 2. Frequency responses to the statement good and evil

(Married man who is an adulterer)

Figure 3 displays the frequency count of responses to the statement الزَّانِي النَّتَّبُ (Married man who is an adulterer). From the 41 participants, sixty-three percent provided wrong translation, whereas only fifteen percent

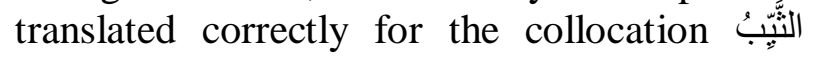

الزًّاني . Meanwhile, twenty-one participants used transliteration to render the collocation

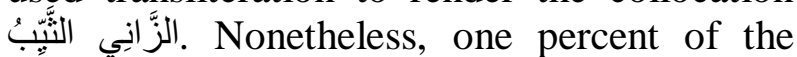
participants offered incomplete meaning to the

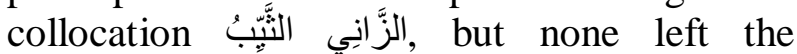
question unanswered. Figure 3 shows the results from the translation test of the thirtyfive participants.

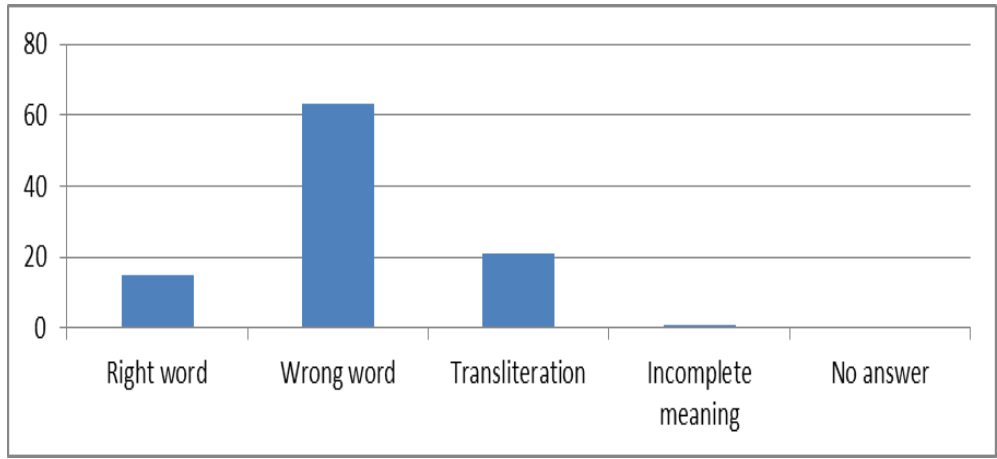

Figure 3. The frequency responses to the statement Married man who is an adulterer

\section{غيظا كَظََ (To suppress rage)}

Figure 4 presents the frequency count of

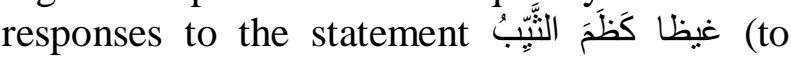
suppress rage). Out of the 41 participants, eighty-three percent gave wrong translation, while only a mere five-percent translated correctly for the collocation غيظًا كَظَّ. Besides, fifteen participants used transliteration to render the collocation غيظًا كَظَّم. Nonetheless, seven percent of the participants gave partial answer to the collocation غيظا كظَ (to suppress rage), while none left the question blank. Figure 4 displays the results from the translation test of the thirty-five participants.

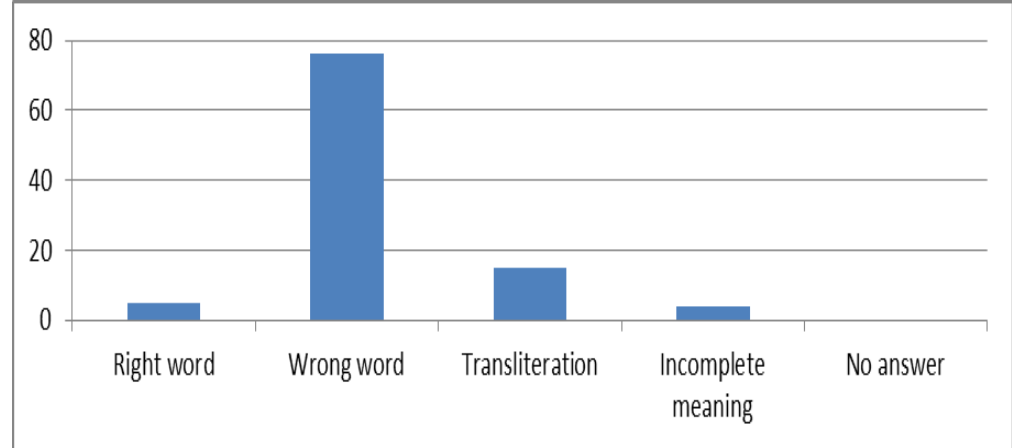


Figure 4. The frequency responses to the statement to suppress rage

\section{الَْنْسُوخُ الْحَيثُ}

Figure 5 exhibits the frequency count of responses to the statement الََْنْسُو خُ الْحَديثنُ (Abrogated Hadith). From the 41 participants, sixty-eight percent gave wrong translation, while only five percent had provided the right translation to the collocation الَْنَسُوُْ الْحَدِيثُ. Besides, fifteen participants used transliteration to render the collocation الْحَديثُ الَْنْسُوُُْ. Nevertheless, eight percent gave incomplete meaning, whereas four percent of the participants did not provide any answer to

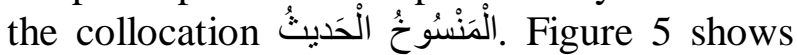
the results from the translation test of the thirty-five participants.

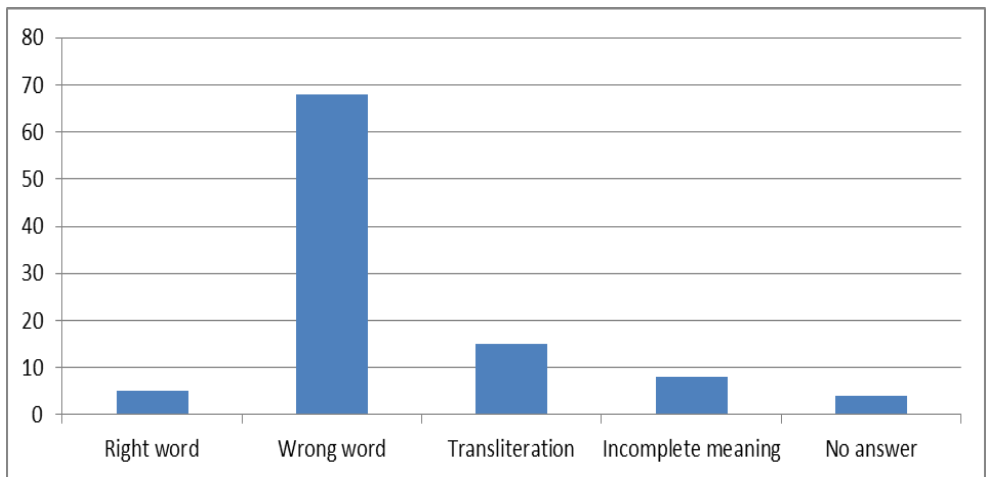

Figure 5. The frequency responses to the statement Abrogated Hadith

\section{الْمَوْتِ سكرةُ (Agony of death)}

Figure 6 displays the frequency count of responses to the statement ال (Abrogated Hadith). From the 41 participants, fifty-four percent translated wrongly, while only four percent gave correct translation for the collocation الَْنْسُوُْ الْحَديثُ. Besides, twenty- two participants used transliteration to render the collocation الََْنْسُوُْ الْحَدَيثُ. However, fifteen present answered partially, while five percent did not give any answer to the collocation الََْنْسُوُْ الْحَديثُ. Figure 6 describes the results from the translation test carried out upon the thirty-five participants.

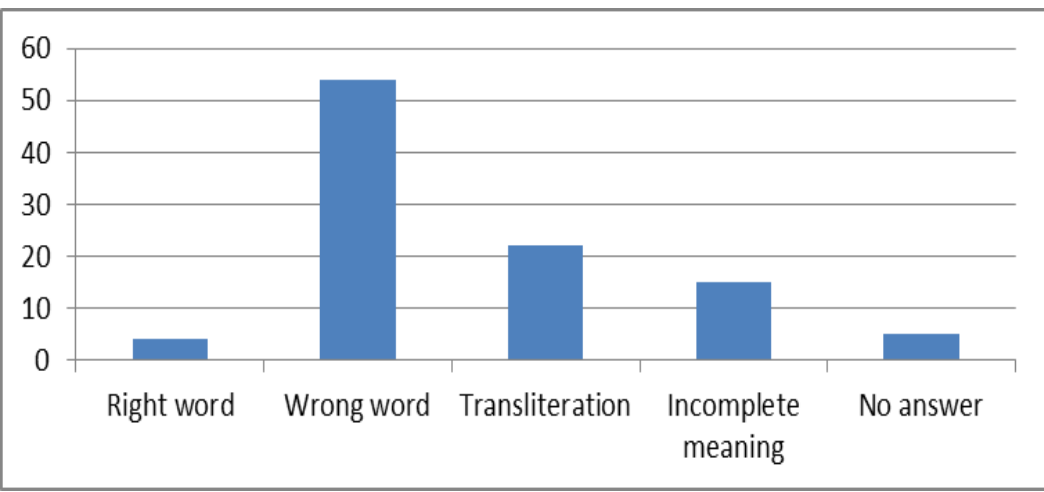

Figure 6. The frequency responses to the statement Abrogated Hadith

\section{يرزق حَيَّ (Alive and kicking)}

Figure 7 shows the frequency count of responses to the statement يرزق حَيَّ (alive and kicking). Out of the 41 participants, eightynine percent gave wrong translation, whereas only eight percent gave the correct translation to the collocation يرزق حَيَّ. Meanwhile, two participants used transliteration to render the collocation يرزق حَيَّ. However, none gave partial meaning or blank answer for this collocation. Figure 7 shows the results from the translation test of the thirty-five participants. 
Amin Ali Al Mubarak

Strategies constrains in rendering Islamic religious collocations from Arabic into English

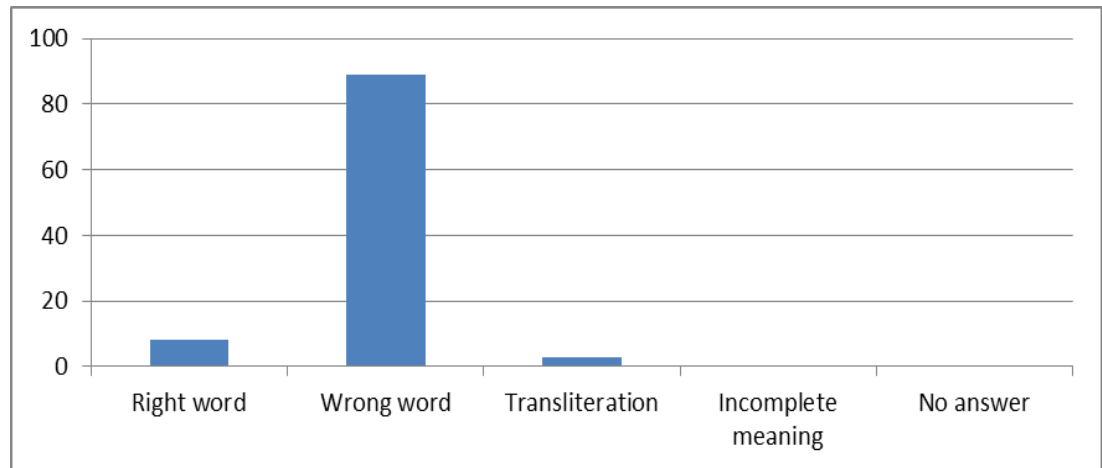

Figure 7. The frequency responses to the statement alive and kicking

\section{مَهِين عَذَابُ (A torment ignominious)}

Figure 8 shows the frequency count of responses to the statement عَهِين عَذَابُ (a torment ignominious). From the 41 participants, a whopping ninety-two percent translated wrongly, while only three percent translated correctly for the collocation عَهِين عَذَابُ
Meanwhile, four participants used transliteration to render the collocation ق مَهِين meaning, but none gave blank answer for the collocation عَدِين عَذَبُ. Figure 8 describes the results from the translation test carried out upon the thirty-five participants.

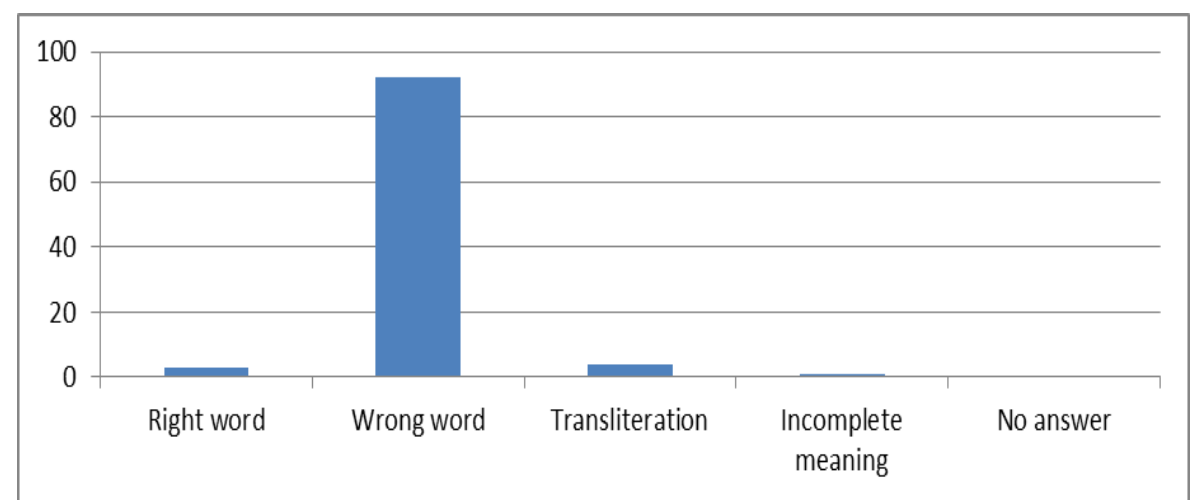

Figure 8. The frequency of responses to the statement a torment ignominious

\section{شَدَيدُ عَذَابُ (A terrific doom)}

Figure 9 shows the frequency count of responses to the statement شَدِيدُ عَذَابُ (a torment ignominious). Out of the 41 participants, seventy-two percent gave wrong translation, while sixteen percent translated correctly for the collocation عَهِين عَذَبُ. Meanwhile, nine participants used transliteration to render the collocation شَدِيدُ عَذَابُ However, two percent gave partial meaning, whereas one percent of the participants did not answer. Figure 9 describes the results from the translation test carried out upon the thirty-five participants.

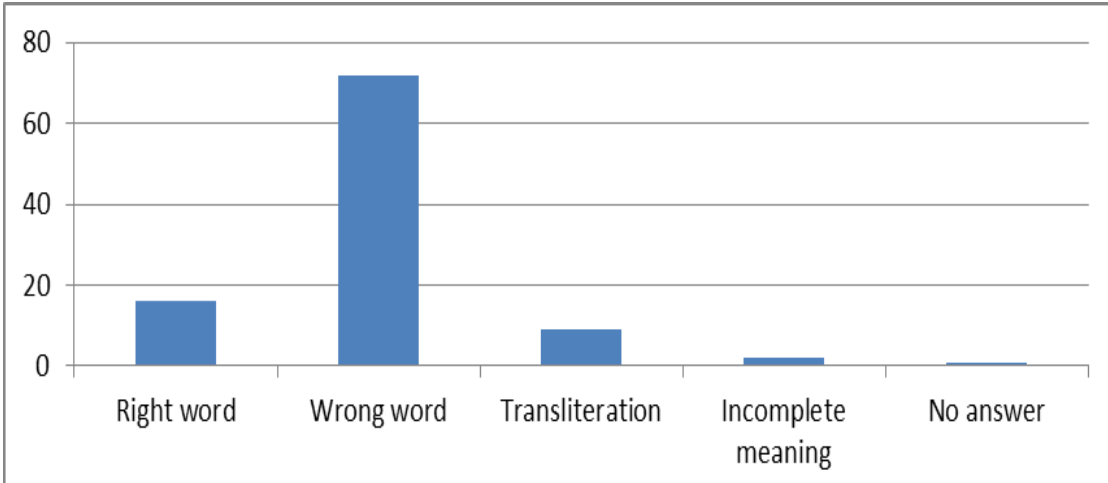

Figure 9. The frequency responses to the statement a torment ignominious 
Indonesian Journal of Learning and Instruction

\section{عَظِيٌُ عَذَبُ (An awful doom)}

Figure 10 shows the frequency count of responses to the statement عَظِيٌُ عَذَابُ (an awful doom). From the 41 participants, eighty-five percent gave wrong translation, while only eight percent gave the right translation to the collocation عَهِين . مَذَابُ . Meanwhile, four participants used transliteration to render the
p-ISSN 2614-8250, e-ISSN 2614-5677

https://journal.uniku.ac.id/index.php/IJLI

collocation عَظِيُُ عَذَابُ However, two percent gave incomplete meaning, while one percent did not provide any translation for the collocation عَظِيٌُ عَذَابُ . Figure 10 describes the results obtained from the translation test that was carried out upon the thirty-five participants.

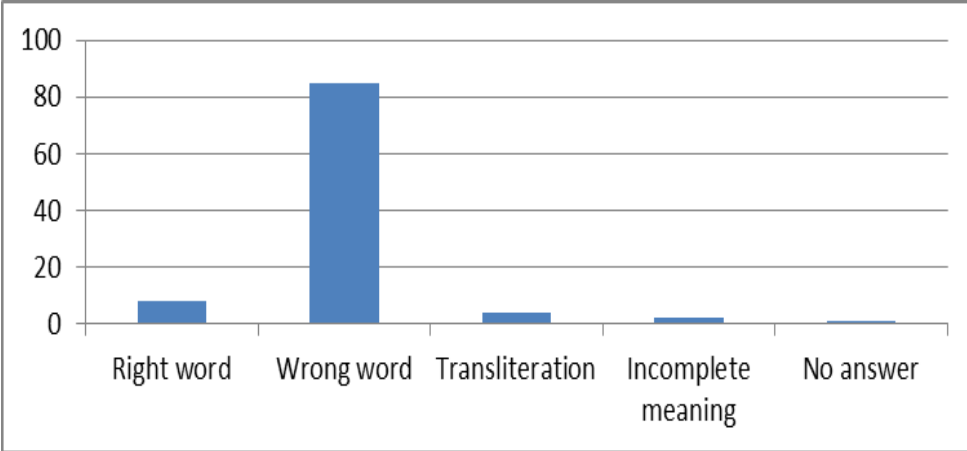

Figure 10. The frequency responses to the statement an awful doom

Religious expressions are an indispensable part of the Muslim culture and they have a strong impact upon their daily life. Thus, deciphering daily conversations, which are full of religious expressions, into English requires a comprehension of the cultural nuances of Islamic expressions, as well as deep knowledge of the teaching of Islam. Besides, the findings showed that Islamic religious collocations are in fact, the actual barriers for students to translate from Arabic language into English language. Furthermore, translators of Islamic religious collocations should be extremely conscious of the variances between Arabic language concepts and beliefs, as well as the English language. Moreover, it is not always a simple job to do since most of the religious expressions are typically determined implicitly rather than unambiguously.

In addition, a term related to religious circumstance differs from the meaning of a similar term in another situation because religious expressions are more expressive and enthusiastic. Furthermore, the findings of the study that are related to the problems encountered by graduate students while translating Islamic religious collocations from Arabic into English showed that most learners found it difficult to achieve the equivalent effects of the cultural and religious terms used in the test. This outcome is in agreement to that claimed by Newmark (1988), as he expressed that "the more culturally remote in time and space a content is, there is less corresponding effect, unless the reader is creative, sensitive, and saturated in the source language culture." This finding also shares with that opined by Aldahesh (2008), who found that inability to meet the correspondence is indeed a dire issue.

The results demonstrated that adopting and deciding a suitable translation method was another problem that the students experienced. This is because; many students either utilized glossing or literal translation method without providing any footnote or explanation for the reader. It further demonstrates that in some cases, the learners depended on the guessing technique, which means, depending on the setting to decide the meaning. Regardless of the significance of the unique situation, it might not be, unfortunately, helpful when it comes to religious expressions because religious terms, for instance, are most of the time used within a particular context. The findings showed that the students were highly influenced by their culture, as reflected in their translation. Furthermore, cultural variances make the translation process a challenging task 
for fellow translators in general, and learners specifically.

On top of that, the study revealed that the reason behind these issues is the lack of cultural awareness that play a major role behind these issues. This finding is in agreement with that of Olk (2003), whose review portrayed that the learners were frequently in need of adequate knowledge about the British culture, which caused them to utilize inadequate renditions. However, the study revealed that unfamiliarity with translation strategies could also be an influential factor for these difficulties. The study revealed that the incorrect rendering of lexical collocations relied mostly on the various strategies adopted by the students in translating the intended collocations. The two most prominent strategies used by the learners were deletion and synonymy. Sometimes, the students gathered some synonyms for lexical constituents that led to collocation clash, whereby the learners proved their lack of knowledge upon collocation issues in translation. Besides, deletion and leaving collocation constituents translated were among the other criteria that displayed the lack of knowledge upon lexical collocations among students.

Furthermore, Islamic religious collocations become a hindrance in the process of translation not only because they need serious search and acquaintance of the target language culture, but also due to the narrow choices of suitable approaches or methods to deal with them (Saleh et al., 2011). In addition, the data analysis offers evidence that the students committed errors of lexical and semantic sorts when translating collocations of religious nature. Incorrect translations are mostly ascribed to the participants' unfamiliarity with specific collocations in both the source language and in the target language, as well as their limited ability in recognizing collocations in their first language. The students also exhibited absence in collocation knowledge due to two factors. The first factor is related to the fact that collocations in religious texts have low occurrence in everyday language, so the translators do not frequently have adequate acquaintance to such categories.

Subsequently, the learners could not recognize two comparable lexical items in Arabic and this particular disarray was reflected in their English translations, which is in agreement with the notion drawn by Baker (1992). Meanwhile, the second factor refers to the combination of lexical items within a given structure conditioned by certain semantic sorts, which limit the collocation choice of those items, which happens to be similar to the assertion made by Bahumaid (2006). Similarly, the terms that derive from the Islamic religious collocation require cultural knowledge to be accurately comprehended to avoid glitches in translation. The complexities embedded in the translation of cultural concepts, as well as the variety of translation techniques applied to describe their sense via interpretation of the lexis from the Arabic Islamic religious collocations, had been examined. As a result, it was discovered that those problems emerged from several linguistic aspects, inclusive of the absence of the cultural concept in the target language, the various semantic fields of the Islamic religious collocation terms in the source language and the target language, the loss of meaning, as well as the metaphorical meaning carried by many culturally associated terms.

These variations point towards a cultural gap that makes the translation of cultural lexis a difficult task, which is similar to the findings reported by Bekkai (2010). Moreover, most of the translation problems faced by the students, as determined in this study, can be grouped under several factors, such as the cultural difference between Arabic language and English language, the misuse of the literal translation approach, as well as the lack of one-to-one equivalents between Arabic language and English language in terms of Islamic religious collocation. Additionally, when students were unfamiliar with the translation strategy known as omission, it was difficult for them to decide when or where to delete or add concepts in the target language.

The results further emphasized the issues that revolve around Islamic religious collocation faced by the students during the 
translation process. For instance, they failed to give a suitable and the real meaning of the Islamic religious collocation from the Arabic language into the target language precisely, which affected the degree of translation quality, as the participants in this study obviously could not translate them successfully. In addition, translation is not an easy activity, which can simply be carried out by anyone. Translators are always faced with confusing problems and complications while translating, which demand a certain capacities and competences on their part. It is important for translators to be more conscious and well accustomed with the cultural environment of the target language to produce meaningful translations. As such, the knowledge of a translator concerning the second language culture is considered as an indispensable requirement for successful translation within specific cultural concepts.

\section{CONCLUSION}

This study has thrown some light on a topic related to Arabic and English translation with special emphasis on the translation of Islamic religious collocation. Besides, the primary objective of this study has been to identify the problems encountered by some selected students when translating Islamic religious collocation from Arabic into English, which has been highlighted through a translation test carried out as a tool for data collection in this study.

Moreover, the findings of this research show that the students in this study faces a degree of difficulty in translating Islamic religious collocation from Arabic into English, which can substantially affect the level and the quality of teaching in the university, where this study has been taken place. In addition, the difficulties are faced by the students in translating the Islamic religious collocations from Arabic into English have been analyzed as the main objective in this study. Thus, in order to attain the objective of the study, the researcher devises the research question to discover and to describe the experiences of the students while translating Islamic religious collocations from Arabic into English.
Consequently, the outcomes of this study are successfully answered the research question: "what are the difficulties the students faced in rendering collocations of religious texts from Arabic language into English language?" As a result, many factors discovered to emerge as problems when translating Islamic religious collocations of Arabic into English. These include the fact that the student may possess poor knowledge of the target language in relation to religious collocation terms, as well as their lack of awareness upon the dissimilarities between the source and the target cultures. Hence, they fail to display a decent understanding regarding the cultural contexts of another language. Moreover, most of these Islamic religious collocations represent implicit meaning embedded within the linguistic structures. As such, they are conventionally, culturally, and pragmatically associated, along with being peculiar to Arabic.

\section{REFERENCES}

Abdelwali, M. (2007). The loss in the translation of the Qur'an. Translation Journal, 11(2).

Al-Khanji, R., \& Hussein, R. (1999). Assessing English collocational knowledge among advanced learners. Mu'tah Lil-buhuth Waddirasat, 14, 129-159.

Aldahesh, A. (2008). Translating idiomatic English phrasal verbs into Arabic. College of Arts: University of Western Sydney.

Bahumaid, S. (2006). Collocation in English-Arabic translation. Babel, 52(2), 133-152.

Baker, M. (1992 ). In other words: A coursebook on translation. Routledge.

Baker, M. (1992, p.97). In other word: A course book on translation. London, UK: Routledge.

Bekkai, M. (2010). The influence of culture on Arabic/English/Arabic translation of idioms and proverbs.

Carter, R. (2012). Vocabulary: Applied linguistic perspectives. Routledge.

Chebbo, A. A. (2006). Arabic to English translation of Islamic religious texts. American University of Sharjah.

Cowie, A. P. (1981). The treatment of collocations and idioms in learners' dictionaries. Applied linguistics. 2223.

Dalby, A. ( 1998 ). Dictionary of languages: The definitive reference to more than 400 languages. London: A \& C Black Publishers.

Dweik, B. S., \& Abu Shakra, M. M. (2011). Problems in translating collocations in religious texts from Arabic into English. Linguistics Journal, 5(1). 


\section{Amin Ali Al Mubarak}

Strategies constrains in rendering Islamic religious collocations from Arabic into English

Dweik, B. S., \& Suleiman, M. (2013, p.78). Problems encountered in translating cultural expressions from Arabic into English. International Journal of English Linguistics, 3(5).

Elewa, A. (2014). Features of translating religious texts. Journal of Translation, 10(1), 25-33.

Esposito, J. L. (2004). The oxford dictionary of Islam. Oxford University Press.

Firth, J. R. (1957). Applications of general linguistics. Transactions of The Philological Society, 56(1), 114.

Garcia, A., \& Francisco. (1996). On translating figurative language from English into Spanish: A perceptual problem. Babel, 42(3), 158-165.

Ghazala, H. (1995). Translation as problems and solutions. Malta: ELGA Publication.

Ghazala, H. (2002). Tarjamatul mustalahatil Islamiati. A paper presented in the symposium on the translation of the holy Quran. Al-Madinatul Munawwaratu: Kingdom of Saudi Arabia.

Halliday, M. A. (1966). Lexis as a linguistic level. In memory of JR Firth. 148162.

Hervey, S. G., Hervey, S., \& Higgins, I. (1992). Lehrbuch. Psychology Press.

Ivir, V. (1987). Procedures and strategies for the translation of culture. Indian Journal of Applied Linguistics, 13(2), 35-46.

Jemiriye, T. F. S. E. (2005). Religion: An introductory study. Ado-Ekiti, Nigeria: Petoa Educational Publishers.

Krings, H. P. (1986). Translation problems and translation strategies of advanced German learners of French (L2). Interlingual and intercultural communication. 263-276.

Larson, M. L. (1984). Meaning-based translation: A guide to cross-language equivalence. University press of America Lanham, MD.

Lörscher, W. (1991). Translation performance, translation process, and translation strategies: A psycholinguistic investigation. G. Narr.
Moon, R. (1998). Fixed expressions and idioms in English: A corpus-based approach. Oxford University Press.

Naudé, J. (2002). An overview of recent developments in translation studies with special reference to the implications for Bible translation. Acta Theologica Supplementum 2.

Newmark, P. (1988). A textbook of translation. New York, USA: Prentice Hall.

Newmark, P. (1989). Paragraphs on translation. Multilingual Matters Limited.

Nida, E. (1969). Eugene \& Charles R. Taber (1969/1982), The Theory and Practice of Translation.

Nida, E. A. (1964). Toward a science of translating: With special reference to principles and procedures involved in Bible translating. Brill Archive.

Olk, H. (2003). Cultural knowledge in translation. ELT Journal, 57(2), 167-174.

Peter, N. (1988). A textbook of translation. New York: TiceHall Press.

Saleh, K. H. A., El-Isa, S., Sameer, E., An, O., \& Hirzallah, R. (2011). Translating restaurants' menus from English into Arabic: Problems and strategies.

Schwartz, S. H., \& Rubel, T. (2005). Sex differences in value priorities: cross-cultural and multimethod studies. Journal of personality and social psychology, 89(6), 1010.

Shunnaq, A. T. (1993). Patterns of repetition in Arabic forced by morphology with reference to ArabicEnglish translation. Papers and studies in contrastive linguistics, 2(8), 89-98.

Zughoul, M. R., \& Abdul-Fattah, H. (2003). Translational collocational strategies of Arab learners of English: A study in lexical semantics. Babel, 49(1), 59-81. 